\title{
The Effect of Profitability and Capital Structure on Firm Value Through Dividend Policy in Transportation Companies Listed on the Indonesia Stock Exchange for the Period of 2015-2018
}

\author{
Samsul Huda ${ }^{1}$, Diana Zuhroh ${ }^{2}$, Achmad Firdiansjah ${ }^{3}$ \\ ${ }^{1}$ Student in Magister Management Program, University of Merdeka Malang \\ ${ }^{2,3}$ Lecturer in Faculty of Economics and Bussiness, University of Merdeka Malang \\ Indonesia
}

\begin{abstract}
This study aims to analyze the effect of profitability and capital structure on dividend policy on transportation companies listed on the IDX for the 2015-2018 period, to analyze profitability and capital structure on Firm Value in transportation companies listed on the IDX for the 2015-2018 period, to analyze the effect of dividend policy on Firm Value in transportation companies listed on the IDX for the 2015-2018 period, and analyzes the effect of profitability and capital structure on Firm Value with dividend policy as an intervening variable in transportation companies listed on the IDX for the 2015-2018 period. The sample in this study were 26 companies. The analysis technique uses path analysis. The results showed that profitability and capital structure had no influence on dividend policy in transportation companies listed on the Indonesia Stock Exchange (BEI) for the period 2015-2018. Profitability and capital structure have an influence on Firm Value in transportation companies listed on the Indonesia Stock Exchange (BEI) for the period 2015-2018. The dividend policy has no effect on Firm Value in transportation companies listed on the Indonesia Stock Exchange (IDX) for the period 2015-2018. This can happen because shareholders only want to get profits quickly or in the short term by taking advantage of capital gains.
\end{abstract}

Keywords: Profitability, Capital Structure, Dividend Policy, Firm Value.

\section{INTRODUCTION}

The current transportation sector is quite interesting to observe its development. Transportation itself is divided between air, land and sea transportation. The most interesting thing to observe is land transportation, along with the shift of public transportation with private vehicles as well as the birth of online transportation which surprisingly has a tremendous impact on the culture of the Indonesian people. Public land transportation under the 2000s was really popular with the people because at that time it was very helpful for the interests of the people who were going to travel. Almost all road routes are passed by public transportation so that people can easily get transportation without having to go to a terminal or bus stop. But over time and the increasing level of the community's economy, people are starting to be able to buy private vehicles for traveling and shifting the role of public transportation. Even today, almost all families have private vehicles to use for travel and are getting rid of public transportation.

The capital structure of a company is also able to support the defense of a company during difficult conditions. Capital structure can affect the company's financial condition, affect the company's stock price, and predict the company's survival. The company's financial condition is the most influential in changing the capital structure, regardless of where the company gets the funds so that it has sufficient funds to finance its needs, both operational and investment needs. Unless the capital structure changes due to a transfer of debt that is converted into equity, the company's financial condition will remain. Capital structure also affects share prices, investors will respond when they see how the company gets the funds to meet their needs. Changes in debt or equity will be of concern to investors, this investor's interest can change the value of shares in a company. The capital structure can also be a reference for investors in predicting company opportunities and risks. The capital structure shows what percentage of debt and equity you have, a debt ratio that is too high has a high risk of default too. However, a small debt ratio is also not entirely good for the company, a debt ratio that is too small makes investors think that the company is afraid of its ability to generate profits to pay its obligations, or that the company's performance is poor so that the profits generated cannot be used to pay debt. 
The capital structure can also be a reference for investors in predicting company opportunities and risks. The capital structure shows what percentage of debt and equity you have, a debt ratio that is too high has a high risk of default too. However, a small debt ratio is also not entirely good for the company, a debt ratio that is too small makes investors think that the company is afraid of its ability to generate profits to pay its obligations, or that the company's performance is poor so that the profits generated cannot be used to pay debt. The capital structure can also be a reference for investors in predicting company opportunities and risks. The capital structure shows what percentage of debt and equity you have, a debt ratio that is too high has a high risk of default too. However, a small debt ratio is also not entirely good for the company, a debt ratio that is too small makes investors think that the company is afraid of its ability to generate profits to pay its obligations, or that the company's performance is poor so that the profits generated cannot be used to pay debt.

Apart from the capital structure, the profitability of a company also affects the stock value or Firm Value in the eyes of investors. High profitability in a company certainly shows a good company performance in generating profits, so that if profits are high, investors believe that dividend distribution will also increase so that investors' profits in investing are clearer and more convincing. The financial ratio between the previous year and the current year can be used as a reference for assessing the company's performance in generating net income. Consistency generates net profit every year and even tends to increase, able to increase investor confidence to provide funds to companies for investment, of course investors also hope to get benefits on that investment. In addition to the profits from dividends, Investors also hope that profits from capital gains, of course companies with good performance in generating net profits will be targeted by many investors, so that the large demand for these shares can increase the value of these shares. When an investor buys a company's stock at the lowest price and sells it when the price is high enough, the investor will benefit from the capital gain.

The dividend policy of a company is quite important in building the confidence of investors who have invested in the company and are able to attract potential investors who will invest in the company. The dividend policy that is routinely carried out by the company is not without reason, but aims to maintain this trust so that investors are still loyal to invest in the company. If there is a condition that investors no longer believe in the company's ability to provide them with profits, then the most likely thing is that investors will flock to withdraw their investment from the company which can reduce the value of the company that has been built so far.

The company's actions in determining dividend policies to increase Firm Value with various objectives should be supported by good profitability and capital structure. Profitability and capital structure are important things that investors see in determining their decisions, so they must be adjusted so that they are able to provide information that attracts investor interest and expectations. The hope is that the company's goals are achieved so as to increase Firm Value.

The number of studies that link profitability and capital structure to firm value adds references and insights on how related these things are. Based on research by Sri Hermuningsih (2012), it shows that profitability and capital structure have a positive influence on firm value [1]. This shows that the level of company profit and the policy on the use of corporate debt provide signals to investors in making decisions that affect firm value. However, a slight difference in the results of the study was conveyed by Luh Gede Sri Artini and Ni Luh Anik Puspaningsih (2011), in their research they stated that profitability had an effect on firm value while capital structure had no effect on firm value [2]. This is because firm value is not influenced by changes in the proportion of debt in the company's capital structure but from other financial decisions such as investments and operations.

The value of the company itself is very important for the company, especially for companies that have gone public and are already listed on the Indonesia Stock Exchange. The company always tries to provide interesting and convincing information for investors in order to gain the trust of investors. Including companies that enter the land transportation sector, with the existence of tight business competition, the company continues to provide a high spirit of optimism that the company is able to rise and earn a net profit every year. Innovations made by companies in the midst of competition are the key to whether or not the company can get out of difficult conditions to return to a safe path and can even go faster.

The final decision remains in the hands of the investor in making his financial decisions. Are investors interested in taking shares of companies that have collapsed in the hope that they can rise and provide multiple returns or are investors reluctant to take risks to invest in companies that do not necessarily provide high returns on their investment. It is interesting to observe again at the level of profitability and capital structure of the company, whether it is able to influence firm value. In ensuring this, researchers are interested in conducting research on whether dividend policies to increase firm value can be achieved if the level of profitability and capital structure is not good. On the basis of these problems, Then the problem that can be investigated is the effect of profitability and capital structure on firm value with dividend policy as an intervening variable for companies in the land transportation sector listed on the Indonesia Stock Exchange. Dividend policy is related to profitability and capital structure, how much dividends the company will pay depends on how the conditions of profitability and capital structure of a company are. The value of the dividend amount is also able to influence firm value because it is able to attract investors' attention and affect shareholder satisfaction, so placing dividend policy as an intervening variable in this study is considered the most appropriate for this reason. 
In addition, researchers want to know the consistency of research results from previous researchers, whether they show the same or different results with the case studies taken in this study. The previous research includes: Sri Hermuningsih (2012) [1] which states that profitability and size have a positive effect on capital structure, and capital structure has a positive effect on firm value, Dwi Retno Wulandari (2013) states that profitability and operating leverage have an effect on firm value, but liquidity has no effect on firm value. [3]. Umi Mardiayati, et al, (2012) stated that dividend policy, debt policy, and profitability have an effect on firm value [4]. Andianto Abdillah (2014) states that dividend policy has no effect on firm value, but debt policy, profitability and investment decisions affect firm value. Lia Setiyawati, et al. (2017) stated that the Dividend Policy has no effect on firm value [5]. Bhekti Fitri Prasetyorini (2013) states that company size, price earning ratio, profitability have an influence on firm value [6]. Ida Ayu Ria Handayani, et al. (2018) stated that profitability has an influence on dividend policy but dividend policy does not mediate profitability and institutional ownership of the value of the company [7]. Luh Gede Sri Artini, Ni Luh Anik Puspaningsih (2011) stated that capital structure has an influence on dividend policy and capital structure has no influence on firm value [2]. Mafizatun Nurhayati (2013) states that liquidity and dividend policy have no effect on firm value [8]. Michell Suharli (2007) states that profitability affects dividend policy and is strengthened by liquidity, while the investment opportunity set does not affect dividend policy [9]. Erni Masdupi (2012) states that capital structure has a negative effect on dividend policy [10]. Muhammad Asril Arilaha (2009) states that profitability affects dividend policy [11]. Maggee Senata (2016) states that dividend policy affects firm value [12]. Ria Nofrita (2013) states that profitability and dividend policy affect firm value, but dividend policy cannot mediate profitability on firm value [13]. Setyadi Wicaksono (2017) states that profitability and dividend policy affect firm value. Zulfia Afifatul Azhar (2018) states that dividend policy can mediate profitability on firm value. And finally Melanie Sugiarto (2011) states that dividend policy has a positive effect on firm value [14].

\section{LITERATURE REVIEW}

\subsection{The value of the company}

Firm value is the value per share marketed in the capital market which can explain how well the company is performing in the eyes of the public. Gitman (2006: 352) explains that Firm Value is the actual value per share that will be received if the company's assets are sold according to the share price [15]. Whereas Brigham, Eugene F and Ehrhardt (2005: 518) explains that firm value is the present value of free cash flow in the future at a discount rate according to the weighted average cost of capital [16].

High corporate value is the goal of every company. The higher the Firm Value, the more prosperous the shareholders will be. The company's and shareholder's wealth is reflected in the market price of the shares, which is a reflection of investment, funding and asset management decisions. The market price of the company's shares that is formed when the seller and the buyer make a transaction is called the firm value. The Firm Value which tends to be stable and increases will attract investors who intend to invest, this promises certainty in their future investments. Therefore it is very important to maintain the company's value in order to remain stable under various conditions.

\subsection{Profitability}

Profitability is the company's ability to generate profits in its efforts to create products or services during a certain period. Kasmir (2015: 22) explains that profitability is a ratio to assess a company's ability to seek profit or profit in a certain period [17]. Profitability describes the company's ability to maximize all available funds to obtain the maximum possible profit. The higher the company gets a return on its business, it shows that the company is able to act and make decisions effectively in every business venture. The company's ability to earn profits certainly attracts investors to invest in the company. The profitability ratio is a measure of how effectively the company manages the company's finances, product marketing, available human resources, and company operations. Brigham, Eugene F and Houston (2003: 107) explain that the profitability ratio is a group of ratios that shows a combination of the effects of liquidity, asset management, and debt on operating results [18]. The profitability ratio aims to measure the company's ability to generate profits. Profitability is also a picture of the future of the company. If the level of profitability in a company is high, the company's future will be guaranteed.

\subsection{Capital Structure}

Capital structure is a comparison between foreign capital and own capital. Foreign capital consists of debt, short-term debt and long-term debt. Own capital consists of retained earnings and may also include company ownership. According to J.Keown et.al (2000), capital structure is a combination or combination of long-term sources of funds used by a person [19]. The capital structure is used by companies to finance various company activities, ranging from operations, business development, and even investments in other companies. 


\subsection{Dividend Policy}

Sartono (2010) explains that dividend policy is a decision whether what the company receives will be distributed to shareholders as dividends or will be retained in the form of retained earnings for investment financing in the future. [20]. Retained earnings are a source of funding in a company that can be used for the benefit of the company or for future investment. Dividend decisions involve two parties with different interests, namely the company and the shareholders. The company wants the profits earned by the company not to be distributed as dividends to shareholders and become retained earnings, on the other hand, shareholders want the maximum dividends from the company for the investment that has been made. The interests of the company are also things that can be understood because the company also needs additional funds to expand the business or finance the production process, while the interests of shareholders are also things that need to be considered by the company. If shareholders are not satisfied with the dividend policy given by the company, they may withdraw their investment in the company because they are not satisfied with the company's dividend policy. Therefore, dividend policy is very important to find the most appropriate point.

\subsection{Hypothesis}

The hypothesis in this study is as follows:

H1: Profitability and capital structure influence dividend policy in transportation companies listed on the IDX.

H2: Profitability and capital structure affect firm value at transportation companies listed on the IDX.

H3: The dividend policy affects the Firm Value of the transportation companies listed on the IDX.

H4: Profitability and capital structure affect firm value through dividend policy on transportation companies listed on the IDX.

\section{RESEARCH METHODS}

\subsection{Definition Operational Variable}

a. The value of the company

Firm value is the price per share resulting from the buying and selling process of shares on the stock market which is influenced by the supply and demand that occurs. The measurement of firm value in this study uses the Tobin's Q indicator. The formulas used in the calculation are:

$$
\mathrm{Q}=\frac{(E M V+D)}{(E B V+D)}
$$

Information:

- Q $\quad=$ The value of the company

- EMV (Equity Market value) = Closing price shares $\mathrm{x}$ number of shares outstanding

- D $\quad=$ Book value of total debt

- EBV $\quad=$ Book value of total assets

b. Profitability

Profitability is the company's ability to utilize all the capital it has to generate profits or profits within a certain period of time. The measurement of profitability in this study uses the Profit Margin indicator. The formulas used in this research are:

$$
\text { Profit Margin on Sales }=\frac{\text { Earning After Interest and Tax }}{\text { Sales }}
$$

\section{c. Capital Structure}

Capital structure is the composition between capital that comes from internal, namely retained earnings and capital that comes from outside, namely debt which must be measured and full of consideration because it will affect the value of the company. Measurement of capital structure in this study uses the Debt to Equity Ratio (DER) indicator. The formula used in this research is:

$$
\text { Debt to Aquity Ratio }=\frac{\text { Total Liabilities }}{\text { Stockholders Equity }}
$$


d. Dividend Policy

Dividend policy is a policy taken by company management to decide how much to distribute to shareholders as dividends or set as retained earnings from generated profits. Dividend policy measurement in this research uses the Dividend Yield indicator. The formulas used in this research are:

$$
\text { Dividend Yield }=\frac{\text { Dividend per Annual Share }}{\text { Market value per share }} \times 100 \%
$$

\subsection{Population and Sampling Techniques}

Population used in research this is a transportation company listed on the Indonesia Stock Exchange with a total of 46 companies. The sampling technique in this study used non-probability sampling with purposive sampling category. These criteria include:

1) All companies in the transportation sector listed on the IDX before 2015.

2) The company has published the company's annual financial statements for the period ended 31 December 2015 to 31 December 2018 in rupiah currency units.

\subsection{Data analysis technique}

The method of analysis used in this research is path analysis. The purpose of using this analysis method is to determine the effect of profitability and capital structure on firm value with dividend policy as an intervening variable. Path analysis in this study contained regression analysis to determine the relationship between variables in order to predict.

\section{RESEARCH RESULTS AND DISCUSSION}

\subsection{Path Analysis}

Path analysis is used to analyze patterns of relationships between variables. This model aims to determine the direct or indirect effect of a set of independent (exogenous) variables on endogenous (bound) variables.

1) Hypothesis 1, namely Profitability (X1) and Capital Structure (X2) have a significant effect on dividend policy (Z) in transportation companies listed on the Indonesia Stock Exchange for the period 2015-2018.

Based on the data on the results of research on each variable, the results of multiple linear regression that have been carried out using the SPSS statistical program are:

Table 1 Results of SPSS Linear Regression Output for Hypothesis 1

\section{Coefficientsa}

\begin{tabular}{|c|c|c|c|c|c|c|}
\hline \multirow{2}{*}{\multicolumn{2}{|c|}{ Model }} & \multicolumn{2}{|c|}{ Unstandardized Coefficients } & \multirow{2}{*}{$\begin{array}{c}\begin{array}{c}\text { Standardized } \\
\text { Coefficients }\end{array} \\
\text { Beta }\end{array}$} & \multirow[b]{2}{*}{$\mathrm{t}$} & \multirow[b]{2}{*}{ Sig. } \\
\hline & & B & Std. Error & & & \\
\hline \multirow[t]{3}{*}{1} & (Constant) & .010 & .003 & & 3,202 & .002 \\
\hline & Profitability & .016 & .016 & .096 & .972 & .333 \\
\hline & Capital Structure & -002 & .002 & -101 & $-1,021$ & .310 \\
\hline
\end{tabular}

a. Dependent Variable: Dividend Policy

\begin{tabular}{|l|r|r|r|r|}
\multicolumn{7}{|c|}{ Model Summary } \\
\hline Model & $\mathrm{R}$ & R Square & $\begin{array}{c}\text { Adjusted R } \\
\text { Square }\end{array}$ & $\begin{array}{l}\text { Std. Error of } \\
\text { the Estimate }\end{array}$ \\
\hline 1 & $.143 \mathrm{a}$ & .020 & .001 & .02092 \\
\hline
\end{tabular}

a. Predictors: (Constant), Capital Structure, Profitability

The value of $\mathrm{R}$ square in the $\mathrm{R}$ Test of determination is $=0.020$

Then $\varepsilon 1=\sqrt{ } 1-\mathrm{R}$ square $=\sqrt{ } 1-0.020=0.80$ 
Based on the data in the table above, it is known that the significance value of the two variables is for profitability $(\mathrm{X} 1)=$ 0.333 , this value is greater than the significance value of $0.05(0.333>0.05)$. These results prove that the variable X1, namely profitability, does not have a significant effect on dividend policy $(\mathrm{Z})$.

While the X2 variable, namely the Capital Structure, has a significance value of 0.310 , this value is greater than the significance value of 0.05 . These results prove that the Capital Structure variable does not have a significant effect on dividend policy (Z).

Based on the data above, the multiple linear regression equation is:

$\mathrm{Z}=\mathrm{b} 1 \mathrm{X} 1+\mathrm{b} 2 \mathrm{X} 2+\varepsilon 1$

$Z=0.096 X 1-0.101 X 2$

From the regression equation above, it can be interpreted:

$\mathrm{Z}$ is the dependent variable whose value is determined by the independent variable. In this study, $\mathrm{Z}$ is the dividend policy on transportation listed on the Indonesia Stock Exchange in 2015-2018.

$\mathrm{b} 1=0.096$ is the amount of contribution of the Profitability variable that affects dividend policy.The regression coefficient value is 0.096 which is positive, meaning that profitability has a positive effect on dividend policy in transportation companies listed on the Indonesia Stock Exchange for the period 2015-2018. This means that the increase in the value of the company's profitability will increase the dividend policy of 0.096 .

b2 $=-0.101$ is the magnitude of the contribution of the capital structure variable that affects dividend policy. The regression coefficient value of -0.101 is negative, which means that if the capital structure variable increases by one unit, the dividend policy value for transportation companies listed on the Indonesia Stock Exchange will decrease by 0.101. So that the capital structure has a negative effect on dividend policy.

$\varepsilon 1=0.80$ is the residual value or possible error of the regression equation model due to the possibility of other variables that can affect variable $\mathrm{Z}$ but is not included in the equation model.

2) Hypothesis 2, namely Profitability (X1) and Capital Structure (X2) have a significant effect on firm value (Y) in transportation companies listed on the Indonesia Stock Exchange for the period 2015-2018.

Based on the data on the results of research on each variable, the results of multiple linear regression that have been carried out using the SPSS statistical program are:

Table 2 Results of the SPSS Multiple Linear Regression Output Hypothesis 2

Coefficientsa

\begin{tabular}{|c|c|c|c|c|c|c|}
\hline \multirow{2}{*}{\multicolumn{2}{|c|}{ Model }} & \multicolumn{2}{|c|}{ Unstandardized Coefficients } & \multirow{2}{*}{$\begin{array}{c}\begin{array}{c}\text { Standardized } \\
\text { Coefficients }\end{array} \\
\text { Beta }\end{array}$} & \multirow[b]{2}{*}{$\mathrm{t}$} & \multirow[b]{2}{*}{ Sig. } \\
\hline & & B & Std. Error & & & \\
\hline \multirow[t]{3}{*}{1} & (Constant) & .516 & .060 & & 8,643 & .000 \\
\hline & Profitability & .620 & .293 & .201 & 2,116 & .037 \\
\hline & Capital Structure & .075 & .031 & .231 & 2,426 & .017 \\
\hline
\end{tabular}

a. Dependent Variable: Firm Value

Model Summary

\begin{tabular}{|l|r|r|r|r|}
\hline Model & $\mathrm{R}$ & R Square & \multicolumn{1}{|c|}{$\begin{array}{c}\text { Adjusted R } \\
\text { Square }\end{array}$} & $\begin{array}{c}\text { Std. Error of the } \\
\text { Estimate }\end{array}$ \\
\hline 1 & $.298 \mathrm{a}$ & .089 & .071 & .38306 \\
\hline
\end{tabular}

a. Predictors: (Constant), Capital Structure, Profitability

The value of $\mathrm{R}$ square is $=0.089$

Then $\varepsilon 2=\sqrt{ } 1-\mathrm{R}$ square $=\sqrt{ } 1-0.089=0.95$

Based on the data in the table above, it is known that the significance value of the two variables is for profitability $(\mathrm{X} 1)=$ 0.037 , this value is smaller than the significance value of 0.05 . These results prove that the $\mathrm{X} 1$ variable, namely profitability, has a significant effect on firm value (Y). 
While the X2 variable, namely the Capital Structure, has a significance value of 0.017 , this value is smaller than the significance value of 0.05 . These results prove that for variable $\mathrm{X} 2$, namely capital structure also has a significant effect on firm value (Y).

Based on the data above, the multiple linear regression equation is:

$\mathrm{Y}=\mathrm{b} 3 \mathrm{X} 1+\mathrm{b} 4 \mathrm{X} 2+\varepsilon 2$

$\mathrm{Y}=0.201 \mathrm{X} 1+0.231 \mathrm{X} 2+0.95$

From the regression equation above, it can be interpreted:

$\mathrm{Y}$ is the dependent variable whose value is determined by the independent variable. In this study, $\mathrm{Y}$ is the value of the company in transportation companies listed on the Indonesia Stock Exchange, whose value is predicted by Profitability and Capital Structure.

$\mathrm{b} 3=0.201$ is the amount of the contribution of the profitability variable that affects firm value. The regression coefficient value of 0.201 is positive, meaning that profitability has a positive effect on firm value. The increase in profitability will cause the Firm Value to increase by 0.201 .

b4 $=0.231$ is the magnitude of the contribution of the capital structure variable that affects firm value. The regression coefficient value of 0.231 is positive, which means that the capital structure has a positive effect on firm value. The capital structure that increases will cause the Firm Value to increase by 0.231 .

$\varepsilon 2=0.95$ is the residual value or possible error of the regression equation model due to the possibility of other variables that can affect variable $\mathrm{Y}$ but not included in the equation model.

3) Hypothesis 3 is that dividend policy $(\mathrm{Z})$ has a significant effect on firm value $(\mathrm{Y})$ in transportation companies listed on the Indonesia Stock Exchange for the period 2015-2018.

Based on the data on the results of research on each variable, the results of multiple linear regression that have been carried out using the SPSS statistical program are:

Table 3 Results of the SPSS Multiple Linear Regression Output Hypothesis 3

Coefficientsa

\begin{tabular}{|c|c|c|c|c|c|c|}
\hline \multirow{2}{*}{\multicolumn{2}{|c|}{ Model }} & \multicolumn{2}{|c|}{$\begin{array}{c}\text { Unstandardized } \\
\text { Coefficients }\end{array}$} & \multirow{2}{*}{$\begin{array}{c}\begin{array}{c}\text { Standardized } \\
\text { Coefficients }\end{array} \\
\text { Beta }\end{array}$} & \multirow[b]{2}{*}{$\mathrm{T}$} & \multirow[b]{2}{*}{ Sig. } \\
\hline & & $\mathrm{B}$ & Std. Error & & & \\
\hline \multirow[t]{2}{*}{1} & (Constant) & .670 & .043 & & 15,629 & .000 \\
\hline & Dividend Policy & $-1,149$ & 1,876 & -.061 & -.612 & .542 \\
\hline
\end{tabular}

a. Dependent Variable: Firm Value

\begin{tabular}{|l|r|r|r|r|}
\multicolumn{7}{|c}{ Model Summary } \\
\hline Model & $\mathrm{R}$ & R Square & $\begin{array}{c}\text { Adjusted R } \\
\text { Square }\end{array}$ & $\begin{array}{c}\text { Std. Error of the } \\
\text { Estimate }\end{array}$ \\
\hline 1 & $.061 \mathrm{a}$ & .004 & -006 & .39855 \\
\hline
\end{tabular}

a. Predictors: (Constant), Dividend Policy

The value of $\mathrm{R}$ square is $=0.004$

Then $\varepsilon 2=\sqrt{ } 1-\mathrm{R}$ square $=\sqrt{ } 1-0.004=0.99$

Based on the data in the table above, it is known the significance value of the $\mathrm{Z}$ variable, namely policy dividend is $=$ 0.542 , this value is greater than the significance value of 0.05 . These results prove that the variable $\mathrm{Z}$, namely dividend policy, does not have a significant effect on firm value $(\mathrm{Y})$.

Based on the data above, the simple linear regression equation is:

$\mathrm{Y} 2=\mathrm{b} 5 \mathrm{Z}+\varepsilon 4$ 
$\mathrm{Y} 2=-0.061 \mathrm{Z}+0.94$

From the regression equation above, it can be interpreted:

$\mathrm{Y}$ is the dependent variable whose value is determined by the independent variable. In this study, $\mathrm{Y}$ refers to the value of the company in transportation companies listed on the Indonesia Stock Exchange, whose value is predicted by dividend policy.

b5 $=-0.061$ is the amount of contribution of the dividend policy variable that affects firm value. The regression coefficient value of -0.061 is negative, which means that dividend policy has a negative effect on firm value in transportation companies in this study. The decline in Firm Value is 0.061 if the company implements dividend policy.

4) Hypothesis 4, namely Profitability (X1) and Capital Structure (X2) have a significant effect on firm value (Y) through dividend policy $(Z)$ in transportation companies listed on the Indonesia Stock Exchange for the period 2015-2018.

Based on the data on the results of research on each outcome variable, the results of multiple linear regression that have been carried out using the SPSS statistical program are:

Table 4 Results of the SPSS Multiple Linear Regression Output Hypothesis 4 Coefficientsa

\begin{tabular}{|c|c|c|c|c|c|c|}
\hline \multirow{2}{*}{\multicolumn{2}{|c|}{ Model }} & \multicolumn{2}{|c|}{$\begin{array}{c}\text { Unstandardized } \\
\text { Coefficients }\end{array}$} & \multirow{2}{*}{$\begin{array}{c}\begin{array}{c}\text { Standardized } \\
\text { Coefficients }\end{array} \\
\text { Beta }\end{array}$} & \multirow[b]{2}{*}{$\mathrm{t}$} & \multirow[b]{2}{*}{ Sig. } \\
\hline & & B & Std. Error & & & \\
\hline \multirow[t]{4}{*}{1} & (Constant) & .528 & .063 & & 8,381 & .000 \\
\hline & Profitability & .637 & .295 & .207 & 2,157 & .033 \\
\hline & Capital Structure & .073 & .031 & .225 & 2,346 & .021 \\
\hline & Dividend Policy & $-1,094$ & 1,828 & -.058 & -.599 & .551 \\
\hline
\end{tabular}

a. Dependent Variable: Firm Value

Model Summary

\begin{tabular}{|l|c|c|c|c|}
\hline Model & $\mathrm{R}$ & $\mathrm{R}$ Square & $\begin{array}{c}\text { Adjusted R } \\
\text { Square }\end{array}$ & $\begin{array}{c}\text { Std. Error of the } \\
\text { Estimate }\end{array}$ \\
\hline 1 & $.303 \mathrm{a}$ & .092 & .065 & .38428 \\
\hline
\end{tabular}

a. Predictors: (Constant), Dividend Policy, Profitability, Capital Structure

The value of $\mathrm{R}$ square is $=0.092$

Then $\varepsilon 3=\sqrt{ } 1-\mathrm{R}$ square $=\sqrt{ } 1-0.092=0.95$

Based on the data above, it is known that the significance value of the variable $\mathrm{X} 1$ is for profitability $(\mathrm{X} 1)=0.033$, this value is smaller than the significance value of 0.05 . These results prove that the $\mathrm{X} 1$ variable, namely profitability, has a significant effect on firm value (Y). Meanwhile, the variable X2, namely the capital structure, has a significance value of 0.021 , this value is less than 0.05 . These results prove that the capital structure variable has a significant effect on firm value. For variable $\mathrm{Z}$, namely dividend policy has a significance value of 0.551 , this value is greater than a significance value of 0.05 , this result proves that dividend policy has no significant effect on firm value.

Based on the data above, the multiple linear regression equation is:

$\mathrm{Y} 1=\mathrm{b} 1 \mathrm{X} 1+\mathrm{b} 2 \mathrm{X} 2+\varepsilon 1$

$$
\mathrm{Y} 1=0.096 \mathrm{X} 1-0.101 \mathrm{X} 2+0.80
$$

$\mathrm{Y} 2=\mathrm{b}_{3} \mathrm{X} 1+\mathrm{b} 4 \mathrm{X} 2+\mathrm{b} 5 \mathrm{Z}+\varepsilon 2$

$\mathrm{Y} 2=0.207 \mathrm{X} 1+0.225 \mathrm{X} 2-0.058 \mathrm{Z}+0.95$ 


\section{Figure 1}

Path diagram X1 and X2 against Y1 through $\mathrm{Z}$

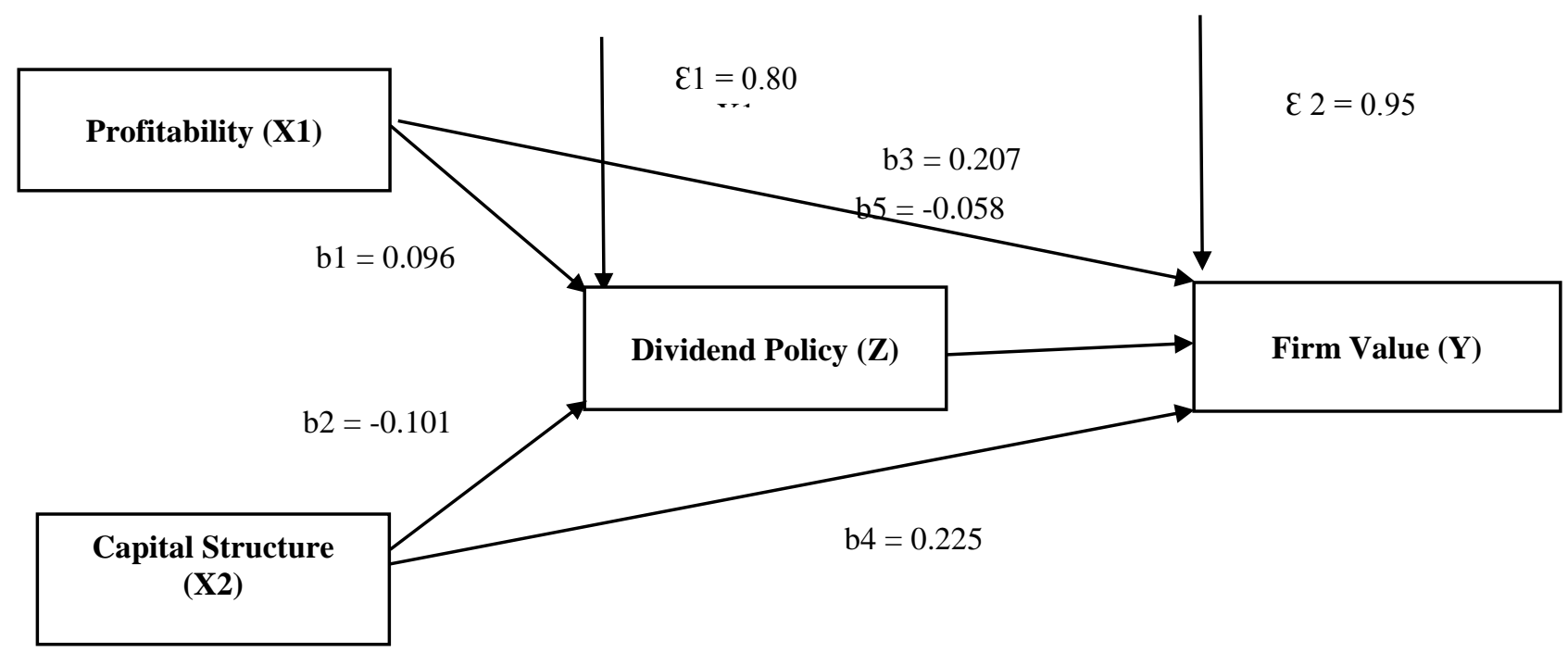

To determine the direct and indirect effect of variable X1, namely profitability on firm value (Y) through dividend policy (Z), namely:

- $\quad$ The direct effect of profitability (X1) on firm value (Y) is 0.207

- $\quad$ The indirect effect of profitability (X1) on firm value (Y) through dividend policy $(\mathrm{Z})$ is: $0.096 \mathrm{x}-0.058=-0.055$

- The effect of total profitability (X1) on firm value (Y) is the direct effect plus the indirect effect, namely:

$0.207+-0.055=0.12$

Based on the calculation of the value above, the value of the direct effect, which is equal to 0.207 , is greater than the value of the indirect effect, namely - 0.055, which means that the direct effect is greater than the indirect effect, this result shows that directly profitability has a significant effect on firm value without going through the policy. dividend. Or there is no effect of profitability on firm value through dividend policy.

While the direct and indirect effect of variable X2 is the capital structure on firm value (Y) through dividend policy (Z), namely:

- $\quad$ The direct effect of capital structure (X2) on firm value (Y) is 0.225

- $\quad$ The indirect effect of capital structure $(\mathrm{X} 2)$ on firm value $(\mathrm{Y})$ through dividend policy $(\mathrm{Z})$ is: $-0.101 \mathrm{x}-0.058=0.058$

- $\quad$ The effect of total capital structure (X2) on firm value (Y) is the direct effect plus the indirect effect, namely: $0.225+0.0058$ $=0.2308$

Based on the calculation of the value above, the value of the direct effect, which is 0.225 , is greater than the value of the indirect effect, which is 0.0058 , meaning that the direct effect is greater than the indirect effect, this result shows that directly the capital structure has a significant effect on firm value without going through a policy. dividend. Or there is no influence of capital structure on firm value through dividend policy.

\subsection{Discussion}

\section{1) Effect of Profitability and Capital Structure on Dividend Policy}

Based on the results of hypothesis testing in Table 1 above, it shows that profitability and capital structure have no effect on dividend policy. Profitability has no influence on the dividend policy of transportation companies listed on the Indonesia Stock Exchange for the 2015-2018 period. This shows that the size of the profitability does not affect the dividend policy of transportation companies listed on the Indonesia Stock Exchange for the 2015-2018 period. This result can be obtained because in that time period not many transportation companies distributed dividends even though the company had recorded a profit. Some companies choose not to distribute dividends and make retained earnings to be used as operating expenses.

These results are in line with the results of research from Ria Nofrita (2013). [13]which states that there is no influence between the profitability variable and the dividend policy variable. However, the results of this study are not in line with the results of research by Muhammad Asril Arilaha (2009) [11], Michell Suharli (2007) [9], Mafizatun Nurhayati (2013) [8], Ida Ayu Ria Handayani et al. (2018) [7]which states that there is an influence between the profitability variable and dividend policy. 
Capital structure has no effect on dividend policy. This shows that the fluctuation of the value of the capital structure does not change the dividend policy of transportation companies listed on the Indonesia Stock Exchange for the period 2015-2018. however, the increasing capital structure still does not change the dividend policy of transportation companies. The large number of transportation companies on the Indonesia Stock Exchange that recorded losses made the company decide not to distribute dividends. The value of the company's capital structure, which is calculated using the Debt to equity ratio, shows a high enough value and means that the company's independence in financing its operations needs to be questioned, so it is relevant if the company decides not to distribute dividends. This is sufficient to explain why the capital structure does not affect dividend policy.

This result is in line with the results of research by Erni Masdupi (2012) which states that there is no influence between the capital structure variable and dividend policy [10]. However, the results of this study are not in line with the results of research by Luh Gede Sri Artini (2011) which states that there is an influence between the variable capital structure and dividend policy [2]

\section{2) Effect of Profitability and Capital Structure on Firm Value}

Based on the results of hypothesis testing in Table 2 above, it shows that profitability and capital structure have a significant effect on firm value. Profitability has an influence on Firm Value in transportation companies listed on the Indonesia Stock Exchange for the period 2015-2018, which can be concluded that the higher the company's profitability value, the higher the Firm Value. Companies that generate high profitability value certainly illustrate that the company is able to collect profits so that potential investors are also sure that in the future the company will be able to provide returns on the investment made, either from dividends or capital gains. These results are in line with the results of research from Ria Nofrita (2013) [13], Mafizatun Nurhayati (2013) [8], Ida Ayu Ria Handayani et al. (2018) [7], Bhekti Fitri Prasetyorini (2013) [6], Andianto Abdillah (2014) [21], Umi Mardiayati et al. (2012) [4], Dwi Retno Wulandari (2013) [3] and Sri Hermuningsih (2012) [1] which states that there is a positive influence between the profitability variable and the firm value variable.

Capital structure has a significant effect on the value of transportation companies listed on the Indonesia Stock Exchange for the period 2015-2018. It can be interpreted that the smaller the value of the capital structure, the higher the firm value. The smaller the value of the capital structure, it means that the company's independence in financing its operations is quite reliable. In transportation companies listed on the Indonesia Stock Exchange for the 2015-2018 period, several companies experienced losses which caused high capital structure value and decreased Firm Value. This is because investors are not sure about the company's ability to rise from a downturn so that they are no longer interested in investing in the company so that the demand for shares decreases so that the company's value also decreases. If the company is able to finance its operations on its own, then the company can be categorized as healthy because it can generate profits for future operations. With these considerations, potential investors will be interested in investing in these shares because it is evident from the company's ability to finance their needs to explain that the company can still generate profits, with the demand for shares rising, the company's value will also go up.

These results are in line with the results of research by Sri Hermuningsih (2012) [1] which states that there is a positive influence between capital structure and firm value variables. However, it is not in line with the research results of Luh Gede Sri Artini et al. (2011) [2] which states that there is no influence between capital structure variables and firm value variables.

\section{3) The Effect of Dividend Policy on Firm Value}

Based on the results of hypothesis testing in table 3 above, it shows that dividend policy has no significant effect on the value of transportation companies listed on the Indonesia Stock Exchange for the 2015-2018 period. This can be because investors who invest in shares of transportation companies prefer to generate short-term gains from capital gains, so that investors do not hold the purchased shares long enough to pay dividends. This can also occur due to the lack of confidence of investors in the company that the company will pay dividends, given the difficult proforma of the company.

This result is in line with the research results of Mafizatun Nurhayati (2013), Lia Setiyawati et al. (2017), Andianto Abdillah (2014) which states that there is no influence between the dividend policy variable and firm value. However, these results are not in line with the results of research from Setyadi Wicaksono (2017), Zulfia Afifatul, et al (2018), Melanie Sugiarto (2011), Ria Nofrita (2013), Magee Senata (2016), Luh Gede Sri Artini et al. (2011), Ida Ayu Ria Handayani et al. (2018), Umi Mardiyati et al. (2012) which states that there is an influence between the dividend policy variable and firm value.

\section{4) The Effect of Profitability and Capital Structure on Firm Value through Dividend Policy}

Based on the results of hypothesis testing in table 4 above, it shows that profitability and capital structure have a significant effect on firm value without going through a dividend policy, or there is no effect of profitability and capital structure on Firm Value through dividend policy in transportation companies listed on the Indonesia Stock Exchange in 2015. -2018. This may imply that even though the company experiences profits, it does not mean that the company provides dividends for shareholders so that investors' expectations of obtaining profits from small dividends can result in decreased interest in stocks, or investors shift their investment objectives from gaining profits through dividends to obtaining profits from capital. gain. In the transportation 
sector, many of these companies record losses, so it is not rational for them to distribute dividends to shareholders so that the decision has a significant effect on Firm Value. Meanwhile, the low capital structure value also does not guarantee that the company will pay dividends to shareholders so that it satisfies shareholders with a return on their investment and attracts investors to invest in company shares and is able to increase the company's value.

This result is in line with the research results of Ida Ayu Ria Handayani et al. (2018) and Ria Nofrita (2013) which state that the dividend policy variable cannot mediate the relationship between the profitability variable and the firm value variable. However, these results are not in line with the results of research from Zulfia Afifatul, et al. (2018) which states that dividend policy can mediate the relationship between the profitability variable and the firm value variable.

\section{CONCLUSIONS AND RECOMMENDATIONS}

\subsection{Conclusions}

Based on the research conducted by researchers, the following conclusions can be drawn:

1) Profitability and capital structure have no influence on dividend policy on transportation companies listed on the Indonesia Stock Exchange (IDX) for the period 2015-2018.

2) Profitability and capital structure have an influence on Firm Value in transportation companies listed on the Indonesia Stock Exchange (BEI) for the period 2015-2018.

3) The dividend policy has no effect on Firm Value in transportation companies listed on the Indonesia Stock Exchange (IDX) for the period 2015-2018. This can happen because shareholders only want to get profits quickly or in the short term by taking advantage of capital gains.

4) Profitability and capital structure have an influence on Firm Value without going through dividend policies on transportation companies listed on the Indonesia Stock Exchange (IDX) for the period 2015-2018.

\subsection{Recommendations}

Based on the research that has been done, it is hoped that further researchers can use or add intervening variables that are more likely to affect firm value. And it is also hoped that further researchers will be able to examine other sectors or sub-sectors besides the transportation service sub-sector, be it services or manufacturing, so that the research results can better describe the conditions on the Indonesia Stock Exchange in more detail.

\section{REFERENCES}

1. Sri Hermuningsih, 2012. Pengaruh profitabilitas, size terhadap nilai perusahaan dengan struktur modal sebagai variabel intervening. Jurnal Siasat Bisnis Vol.16 No.2, 232-242

2. Luh Gede Sri Artini, Ni Luh Anik Puspaningsih, 2011. Struktur kepemilikan dan struktur modal terhadap kebijakan dividen dan nilai perusahaan. Jurnal keuangan dan perbankan, vol.15 no.1 hlm. 66-75

3. Dwi Retno Wulandari, 2013. Pengaruh profitabilitas, operating leverage, likuiditas terhadap nilai perusahaan dengan struktur modal sebagai intervening. Universitas Negeri Semarang.

4. Umi Mardiyati, Gatot Nazir Ahmad, Ria Putri, 2012. Pengaruh kebijakan dividen, kebijakan hutang dan profitabilitas terhadap nilai perusahaan manufaktur yang terdaftar di BEI periode 2005-2010. Jurnal Riset Manajemen Sains Indonesia, Vol.3 No.1

5. Lia Setiyawati, Sugeng Wahyudi, Wisnu Mawardi, 2017. The influence of dividend policy, debt policy, independent commissioner, and institutional ownership on the firm value with growth opportunities as moderator variables (study on non-financial companies listed on IDX in the period of years of 2012-2015). Jurnal Bisnis Strategi Vol 26 (146-162) P-ISSN: 1410-1246, E-ISSN: 2580-1171

6. Bhekti Fitri Prasetyorini, 2013. Pengaruh ukuran perusahaan, leverage, price earning ratio dan profitabilitas terhadap nilai perusahaan. Universitas Negeri Surabaya.

7. Ida Ayu Ria Paramita Handayani, Dodik Ariyanto, Ni Ketut Rasmini, Anak Agung Gde Putu Widanaputra, 2018. The effect of profitabillity, institutional ownership on the value of the company with dividend policy as a meditation. International Journal of Sciences, ISSN 2307-4531

8. Mafizatun Nurhayati, 2013. Profitabilitas, likuiditas dan ukuran perusahaan pengaruhnya terhadap kebijakan dividen dan nilai perusahaan sektor no jasa. Jurnal keuangan dan bisnis, Vol.5, No.2 
9. Michell Suharli, 2007. Pengaruh profitability dan investment opportunity set terhadap kebijakan dividen tunai dengan likuiditas sebagai variabel penguat. Jurnal akuntansi dan keuangan, Vol.9 No.1, 9-17

10. Erni Masdupi, 2012. Pengaruh insider ownership, struktur modal dan pertumbuhan perusahaan terhadap kebijakan dividen perusahaan syariah yang terdaftar di bursa efek indonesia. Economac Volume 12 nomor 1 (9-14).

11. Muhammad Asril Arilaha, 2009. Pengaruh free cash flow, profitabilitas, likuiditas dan leverage terhadap kebijakan dividen. Jurnal keuangan dan perbankan, Vol.13 No.1, hal.78-87

12. Maggee Senata, 2016. Pengaruh kebijakan dividen terhadap nilai perusahaan yang tercatat pada indeks LQ-45 bursa efek indonesia. Jurnal wira ekonomi mikroskil, vol.6 no.1

13. Ria Nofrita, 2013. Pengaruh profitabilitas terhadap nilai perusahaan dengan kebijakan dividen sebagai variabel intervening (studi empiris pada perusahaan manufaktur yang terdaftar di BEI). Universitas Negeri Padang.

14. Melanie Sugiarto, 2011. Pengaruh struktur kepemilikan dan kebijakan dividen terhadap nilai perusahaan dengan kebijakan hutang sebagai intervening. Jurnal akuntansi kontemporer, Vol.3 No.1, hal. 1-25

15. Gitman, J. Lawrance, 2006. Principles of Managerial Finance, Eleven Edition. New Jersey: Pearson Education, Inc.

16. Brigham, Eugene F. Dan Ehrhardth, 2005. Dasar-Dasar Manajemen Keuangan. Edisi Kesembilan. Alih bahasa. Jakarta: Salemba Empat.

17. Kasmir, 2015. Analisis Laporan Keuangan. Jakarta: Rajawali Pers.

18. Brigham, Eugene F. Dan Joul F Houston, 2003. Manajemen keuangan edisi 2. Jakarta: Erlangga

19. J. Keown, Arthur, dkk, 2000. Dasar-Dasar Manajemen Keuangan. Jakarta: Salemba Empat.

20. Sartono, Agus, 2010. Manajemen Keuangan: Teori dan Aplikasi, Edisi keempat, cetakan pertama. BPFE, Yogyakarta.

21. Andianto Abdillah, 2014. Analisis pengaruh kebijakan dividen, kebijakan hutang, profitabilitas dan keputusan investasi terhadap nilai perusahaan manufaktur di BEI periode 2009-2012, Universitas Dian Nuswantoro Semarang. 